\title{
ASPECTS OF REDUCING THE EFFECTS OF VEHICLE-BORNE IMPROVISED EXPLOSIVE DEVICES
}

\author{
Jan Drozd ${ }^{\mathrm{a}}$, Zdenek Flasar ${ }^{\mathrm{b}}$, Luděk Rak ${ }^{\mathrm{c}}$ \\ University of Defence in Brno, Faculty of Military Leadership, \\ Brno, Czech Republic \\ a e-mail: jan.drozd@unob.cz, \\ ORCID iD: (t)http://orcid.org/0000-0003-3257-0473 \\ b e-mail: zdenek.flasar@unob.cz, \\ ORCID iD: iohttp://orcid.org/0000-0002-3328-1879 \\ c e-mail: ludek.rak@unob.cz, \\ ORCID iD: :http://orcid.org/0000-0003-1929-0602
}

http://dx.doi.org/10.5937/vojtehg66-16391

FIELD: Military Science

ARTICLE TYPE: Original Scientific Paper

ARTICLE LANGUAGE: English

\section{Abstract:}

The paper deals with tactical and technical contexts of attacks by vehicleborne improvised explosive devices (VBIEDs). This type of attack is usually conducted aiming at so-called "soft targets", i.e. people who are at a certain moment in the area of a planned attack. The objectives of these attacks can be diverse. The common denominator of attacks is usually to create damaging consequences, especially a large number of dead and injured people. This paper did not focus on the elimination of these attacks, but rather on the reduction of their consequences. Since their assumption is that a complete prevention of these attacks is impossible, the authors formulated some possible solutions, (regarding the technical parameters of the means in particular) to mitigate the consequences of attacks in different ways. Some measures and technical means to mitigate the effects on people are easier to implement while some are more complex and costly.

Key words: vehicle-borne improvised explosive device, barrier, terrorist, protection, explosion.

\section{Introduction}

After seizing Mosul, the Iraqi police confiscated cars which the militants of the so-called Islamic state had converted to armored vehicles used for suicide attacks (see Figure 1). These were modified, mostly armored cars, loaded with large amounts of explosives which could better overcome the defensive fire of Iraqi or Kurdish units - unless hit by 
an anti-tank system. These cars would get to the immediate vicinity of the target where the driver would initiate an explosion. (Zahraničí et al, 2017)

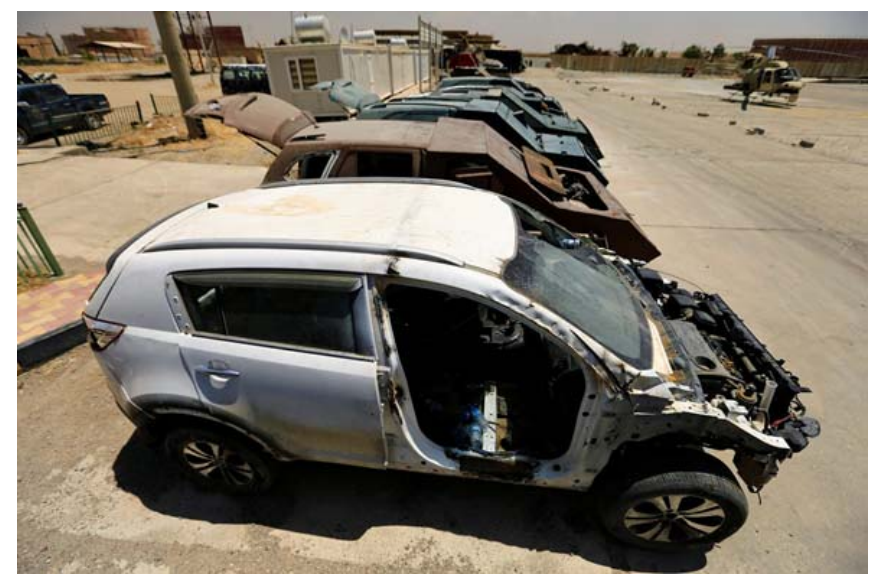

Figure 1 - Seized cars ready for suicide attacks

Pис. 1 - Изъятые автомобили террористов-смертников

Слика 1 - Заплењени аутомобили намењени самоубилачким нападима

The explosion of a truck in the densely populated part of the Somali metropolis of Mogadishu near the Foreign Office had a huge impact. The explosion was so strong that several buildings collapsed, cars burned, and the victims' bodies were torn down on the streets (see Figure 2). The number of people died rose to 276 , while approximately 300 people were injured. (ČTK, 2017)

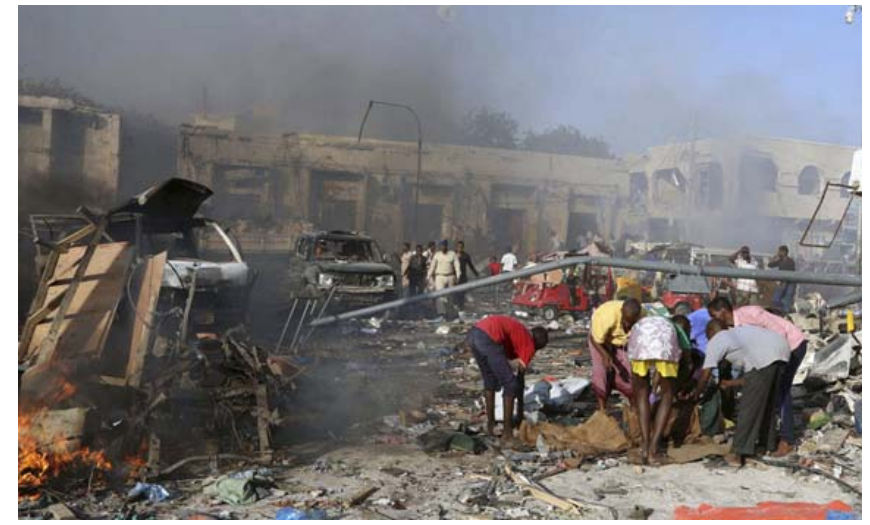

Figure 2 - Consequences of the VBIED attack in Mogadishu Puc. 2 - Последствия подрыва автомобиля в Могадишо Слика 2 - Последице напада импровизованом експлозивном направом у возилу у могадишу 
The use of a vehicle-borne improvised explosive device (VBIED) is a very common way of terrorist attacks, not only in Muslim countries. Terrorists are using VBIEDs in many other cities, including European ones. It is necessary to continuously address the possibilities of protection and defense against VBIEDs and to increase the resistance of potential targets against such attacks. Experience shows that the current methods of fighting VBIEDs, particularly in asymmetric operations and terrorist attacks, can be considered obsolete, inadequate and ineffective. Especially for this reason, this means is increasingly used as a surprise and dangerous enemy weapon. The ordinary ways of conducting battle drills and tactical procedures, the use of small arms, barricades, and possibly anti-tank weapons cannot stop VBIEDs in time. It can be assumed that VBIEDs are and will be used in the future (as evidenced by current incidents in Afghanistan, Syria, terrorist attacks in France, Germany, etc.). Preparing and implementing measures against VBIEDs is essential, especially for the protection of stationary positions, checkpoints, important buildings, command posts, and all areas of deployment. It could be assumed that not only the Czech Army would face problems of missions focused on the protection of the above mentioned potential targets. Moreover, this is already happening not only within the operations but also in the Czech Republic and this situation would most probably be more frequent.

\section{Tactical aspects of countering VBIEDs}

The basic measure against any negative activity is to eliminate the causes of this activity. However, the cause for using a variety of attacks in an unstable environment is so diverse and for a civilized world illogical and atrocious. Fighting the causes of VBIED attacks is more or less impossible. Therefore, it is essential to continuously and intensively focus on measures to reduce the risk of VBIED attacks and to reduce the consequences of their use. (Headquarters, Department of the Army, 2013)

Enemies have a huge advantage when using VBIEDs. They can choose the place and time of use, and in most cases the method of use. In particular, the protection of so-called "soft targets", particularly civilians in populated areas, is very complex. VBIED attacks are far from being directed against "military targets" in the form of bases, military and police buildings and stations, or against embassies and other government institutions. Very frequent are attacks on marketplaces, church buildings, schools, squares, etc. 
The ideal situation would be to prevent attacks completely by taking such measures which would lead to their elimination. But this is hardly ever possible. It is therefore necessary to monitor and evaluate the following in particular:

- the enemy has a reason to attack in the territory; the aim may be to demonstrate its presence, to induce instability and fear, to cause human losses and damage to property of the "opposing party";

- the enemy has the means to perform the attack - human, material and financial;

- territories which are "suitable objects" to attack.

For example, if the monitoring of suspects fails to detect and eventually thwart the attack, the response to a VBIED attack is almost always very difficult. There are objects in unstable zones around which various detectors and technical obstacles, including roadblocks, can be placed in advance. They are government buildings, barracks and police and other stations, i.e. institutions against which the enemy acts actively. These long lasting measures are almost impossible for countless other objects - churches, mosques, marketplaces, shopping centers, squares, etc. At least these measures could be applied on different occasions, such as during religious holidays where there is a significant concentration of people.

So what is the point of focusing on the efforts to fight VBIEDs? From the point of view of barriers, as a defensive measure against VBIEDs and their effects, a number of requirements can be traced in tactical terms:

- if vehicles loaded with explosives are driven by humans, it would be possible to stop or kill the vehicle driver, for example by dimensioning and shaping the barricade. However, this effect would have to occur at such a distance from the "soft targets" to ensure that, even after a controlled or uncontrolled detonation of the explosive, it would not endanger persons and objects in the impact area. Moreover, it is a fact that a number of VBIEDs are driven by suicide bombers who count on their own death.

- as in the previous case (VBIEDs driven by humans), it is a similar case when the vehicle is remote-controlled from its starting position with such a technical device which allows the operator to steer the vehicle, and in the final phase, to initiate explosion. Alternatively, the driver of a VBIED leaves the car at a safe distance.

- the basic requirement therefore appears to be a counter-attack on the vehicle, stopping the vehicle at a safe distance from the target. 
It should be noticed that such a barrier would be necessary to comply with the provisions of the Ottawa Agreement called the Convention on the Prohibition of the Use, Stockpiling, Production and Transfer of AntiPersonnel Mines and on their Destruction. SROV: 5. (ICRC, 1997)

\section{Devices diminishing the consequences of VBIED explosions}

The most common threat to soft targets is represented by an explosion of charge plus a fragmentation charge, regardless of whether it is an improvised device filled only with nails or ball bearings or an industrially produced carbon steel insert. The size of the impact zone with the $100 \%$ threat of the death of an uncovered person due to fragmentation can be expressed by the formula:

$$
R(f)=109.62 \times Q 0.164
$$

where

$R(f)$ - Hazardous Fragmentation Distance Range $(\mathrm{m})$,

$Q$ - trinitrotoluene equivalent of a detonating explosive $(\mathrm{kg})$.

Thus, if a tritol charge equivalent to $10 \mathrm{~kg}$ is considered (insurgents usually use explosives with less efficiency, but in a much larger amount), it forms a circular zone of $159 \mathrm{~m}$ in radius from the explosion point of the charge. The surface threat is $79382 \mathrm{~m}^{2}$ according to the calculation.

If such a charge did not contain a complement to the fragmentation (in the primary and secondary scale) of the material, the lethal effect would only be related to the pressure effect of the exploding ammunition, i.e. by the following formula:

$$
r=K(m) \cdot \sqrt[3]{Q} ;
$$

where

$r$ - the radius from the exploding charge determined by the critical factor $K(m)$,

$K(m)$ - the critical factor for human survival being 10 , for civilian buildings the critical factor of destruction is set at 70 ,

$Q$ - trinitrotoluene equivalent to a detonating explosive in $\mathrm{kg}$.

The uncovered person therefore has a theoretical chance of survival at a distance of 21 meters. The overhead impact of the pressurized charge is $1.384 \mathrm{~m}^{2}$.

From the above mentioned, it is clear that the threat zone caused by fragmentation material represents an area multiplied by almost 57 times. 
This clearly indicates the requirement for a barrier to absorb or repel fragmentation material at least that directed towards a potential target. Unfortunately, most of the material used to make barriers is not only unable to absorb the high-kinetic energy of fragments, but, on the contrary, it itself becomes a secondary fragmentation material. Due to the size of a vulnerable area, it is absolutely necessary to fulfill this requirement so that the barrier has at least the basic ability to neutralize enemy VBIEDs.

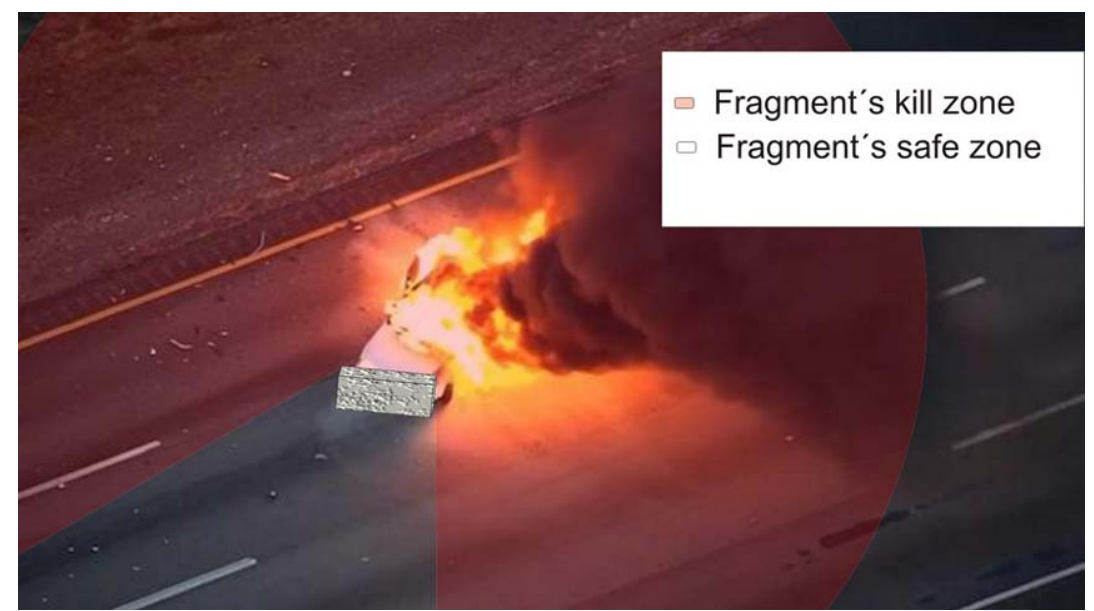

Figure 3 - Zones of fragment effects after explosion

Puc. 3 - Зоны осколочного действия взрыва

Слика 3 - Зоне парчадног дејства експлозије

A very effective device of reducing the effects of VBIEDs may be a barrier that should (and could) perform the following functions (see Figure 3):

- discourage attackers from their intention only by its presence,

- slow down or stop a vehicle with an explosive at such a distance from a soft target that the loss of life is minimized or completely eliminated,

- direct the attacking vehicle into a zone where there are no major consequences after an explosion,

- at least partially absorb explosion fragments directed towards a potential target and thus prevent the death toll from increasing.

The subsequent passages of the article will focus on a technical means to reduce the consequences of VBIEDs - on barriers. 


\section{Basic requirements for devices diminishing consequences of VBIEDs}

There are a number of technical requirements for such devices. It is not possible to compile a "ranking" of requirements for these means in terms of materiality - from the most significant to the least significant. This applies to all technical means, including roadblocks. However, possible requirements include:

- the goals which barriers have to achieve. These objectives may be:

- deterring attackers from their intention to use VBIEDs,

- slowing or stopping attacking vehicles,

- directing attacks (including fragments after the explosion) into less dangerous directions and space;

- mobility of the barrier. This is related in particular to the dimensions of the barricade, its weight, profile and shaping, the number of people to manipulate it, the need for other manipulation techniques, or a battle order. The outcomes from learning in this stage of training include also the issuing of battle order on the terrain.

Mechanization and automation of the barrier could reach such a degree that the barrier could be autonomously mobile, equipped with a "propeller" to move, even with environmental sensors (including the VBIED potential attack evaluation) and automatic shifting to the "vulnerable direction". However, this type of device would be very costly, and would significantly reduce its deployment.

- directing the effect of the attack into a less dangerous area;

- the strength of the location of the barrier at the specified location (adhesion conditions in relation to the lower part of the barrier and the ground on which the barrier is deployed);

- other aspects of the barrier, such as:

- demonstration of force by a transparent barrier or hidden placement of the barrier,

- minimizing the movement of persons and techniques unrelated to any attack in the area of the barrier location,

- aesthetic aspect, and others.

\section{Barrier manipulation}

Mobility of the barrier is an important condition. The ease, simplicity, and speed of barrier installing on the required space need to be taken 
into the consideration as well as picking it up after a VBIED attack and/or relocating it to another vulnerable site.

Only one person (for example, with portable road barrier spike systems) can handle a barrier or there can be up to several people with transport and handling equipment (e.g. heavy concrete segments and prefabricates; see Figure 4).
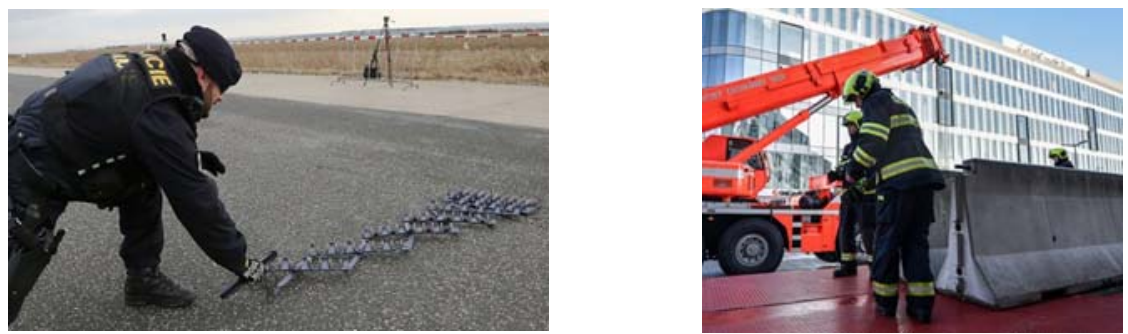

Figure 4 - Application of a portable road barrier spike system and the assembly of prefabricated roadblocks

Puc. 4 - Монтаж временного препятствия с шипами и сборка дорожного барьера

Слика 4 - Постављање привремене препреке са шиљцима и састављање блокова за запречавање пута

\section{Angle of the VBIED direction towards a barrier}

It is also advisable to influence the VBIED attack angle on the barrier. In the perpendicular direction, the result is that the vehicle force acts in the direction of the vehicle's impact. By altering the attack angle, the force is distributed and the resultant force is smaller than the force in the direction of the planned attack on the target.

The angle of attack on the barrier can be predetermined even when installing the barrier - by directing it to the desired direction of the vehicle (resultant forces). However, such a barrier direction is quite obvious to potential attackers, so terrorists can adapt the way and direction of the attack. The incospicuous redirection of the attacking vehicle can be achieved by varying the fixed parts of the barrier in relation to the support on which the barrier is installed (see Figure 5).

The non-clamped side of the barrier is released by the impact of the vehicle and rotates around the center represented by the fixed anchorage pin. The attacking vehicle is then directed where desired. The speed of rotation of the barrier in an unoccupied position can be influenced by the adhesion conditions in relation to the lower part of the barrier and the ground on which the barrier is installed (see the next passage). The desired heading of the resulting movement of the VBIED 
can also be achieved by a subsequent "stopping point" that stops the rotation of the barrier.

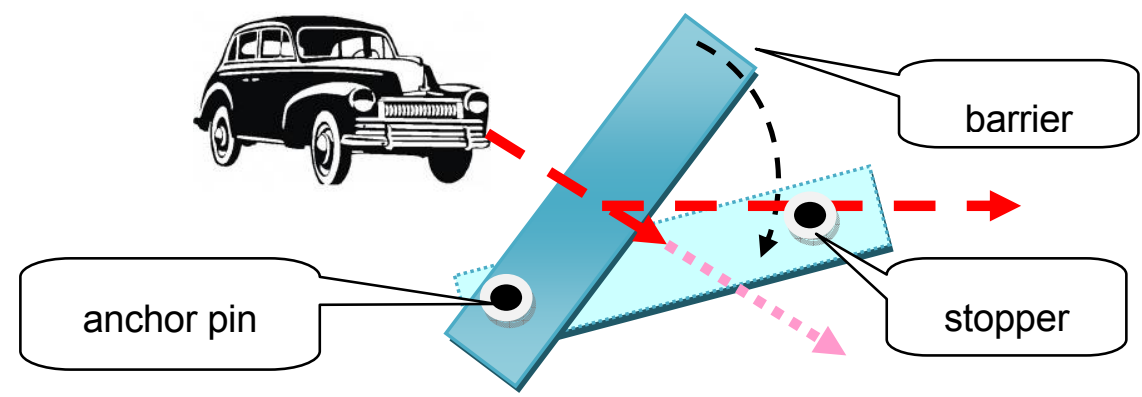

Figure 5 - Anchoring only one side of the roadblock to the base Puc. 5 - Одностороннее крепление блока барьера к основанию Слика 5 - Причвршћивање само једне стране блока баријере за основу

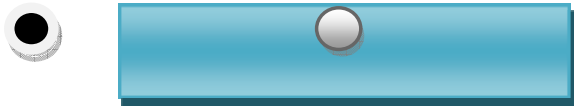

Figure 6 - Anchoring pins of different material Puc. 6 - Крепежные детали из разных материалов Слика 6 - Елементи за причврићивање од различитих материјала

The desired heading of the VBIED in the case of the use of "unequal quality" anchoring of the barrier to the support (anchor pins / pins of different material) can be achieved by anchoring the "shear pin", its dimensions (diameter, cross-section) and material quality (see Figure 6).

\section{Adhesion conditions}

The term "adhesion conditions" can be used to describe the stability of the fixture of the barrier with the ground against VBIEDs. The stability with which the barrier is fixed will certainly influence the weight of the barrier and the area of the lower part of the barrier that is attached to the ground (road surface, etc.). In general, the following could be considered:

- unanchored barricades,

- anchored barriers,

- weight down roadblocks (modular vehicle barriers).

\section{Unanchored barricades}

If the above two significant barrier attributes (weight and contact area) are exceeded, the stability of the position of the barrier at a given 
location will interfere with the interaction of the bottom area of the barrier and the nature of the "pad" on which the barrier will be installed. Both of these surfaces (barrier and pad) can have different structures, e.g.:

- flat, slightly roughened area (in the case of a roadblock such as metal or concrete, in the case of asphalt pavement, paved or other road),

- differently shaped surfaces (so as to fit the lower part of the barrier and the shape of the pad).

Possible shapes of pads

flat compact surface flat non-compact surface flat-shaped surface
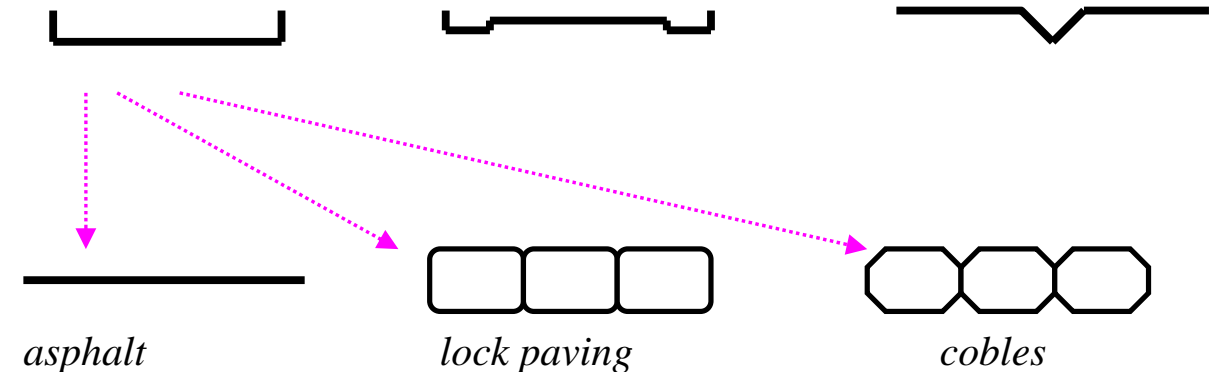

Figure 7 - Interaction of the interlocking surfaces of the barrier and pads

Puc. 7 - Взаимодействие нижней части барьера с основанием

Слика 7 - Интеракција доњих површина баријере и основе

In Figure 7, the arrows show the interaction of the lower part of the barrier with the surface of the pad. It is also possible to express the relationships of all surfaces (the lower parts of the barrier and the surface of the pads).

\section{Anchored barriers}

From the point of view of fulfilling the functions of the roadblock, especially in the sense of stopping VBIEDs, "somehow" anchored barriers appear to be more appropriate. The anchoring may relate to individual sections of the barrier field or to a series of individual barriers which are interconnected, for example, by chains, steel ropes, etc. In the case of anchoring a coupled barrier, it is necessary to bear in mind that after the vehicle has come to any part of the anchor of the barrier field, the whole field will somehow "behave", i.e. it will tend to shift fragments across the barrier field. This phase could shift some fragments into unwanted areas where casualties can be inflicted or objects damaged or destroyed.

Anchoring can be done to any fixed object in the placement of the barrier location, or as a separate function of the barrier itself. A rigid 
anchorage of the barrier to the base can be achieved by pins which "immerse" into the prepared (drilled) holes in the base (for communication, see Figure 8).

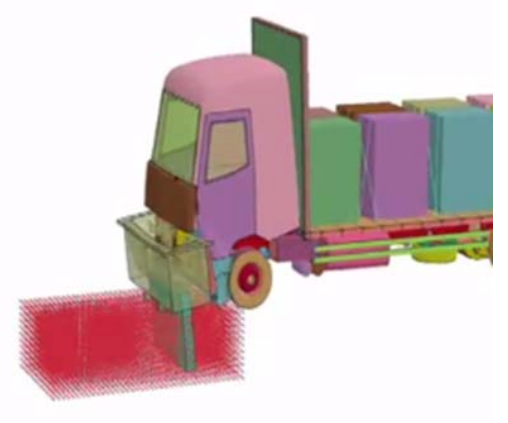

Figure 8-Anchored barrier Puc. 8 - Анкерный барьер Слика 8 - Фиксна баријера

\section{Weight down roadblocks}

As a possibility of combining both concepts, the barrier using the load of the attacking vehicle appears to be an effective solution. Before the vehicle starts pushing this barrier, it loads it by its own weight. Thus, the adhesion increases and the weight as well. Such a barrier is, contrary to the anchor, easy to handle and can provide an adequate degree of protection regardless of its low weight (see Figure 9).

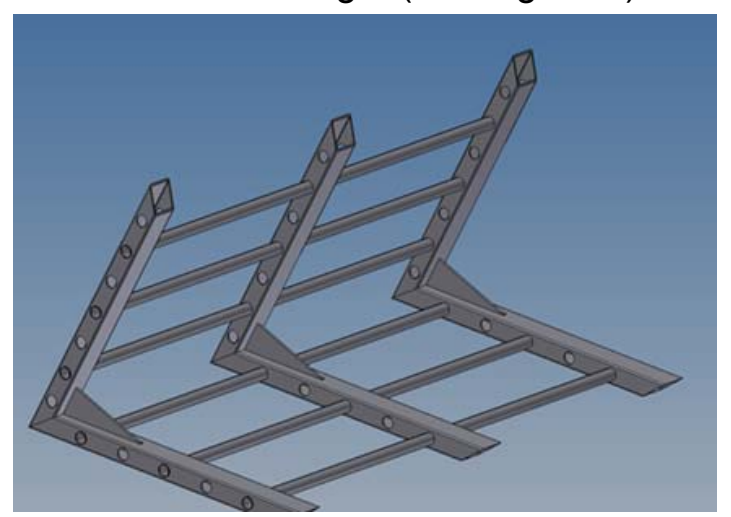

Figure 9 - Possible shaping of a barrier

Рис. 9 - Один из видов барьера

Слика 9 - Један од облика баријере 


\section{Other aspects of barriers}

It is certainly possible to consider other aspects of barriers and requirements for them. Such aspects can include:

- acquisition costs for the whole process - minimal development, verification tests and production;

- costs of installing and reinstalling barriers;

- aesthetics. Particularly in historical or specific, architecturally built areas, "concrete monsters" may appear visually unpleasant. This requirement, of course, cannot have a major effect on the functionality of barriers.

- other requirements and aspects.

Different parts of built-up areas contain objects designed for purposes other than stopping VBIEDs. For example, there may be different decorative posts (sometimes connected by forged chains) around fountains, columns, etc., racks with waste containers, so-called "pins" (pillars connected to the water lines for refreshing passers-by), etc. Barriers could be constructed even as "imitations" of the abovementioned objects and installed in case of danger to the area as an addition to the existing objects (see Figure 10). Of course, the stability requirements would be considerably higher than for common decorative posts, litter bins, etc. Instead of being anchored in the area, stands could be used on sports grounds, volleyball playgrounds, in gymnasiums, etc. In gym floors, there are holes in which the sports racks are inserted and fastened. If posts are not needed, they are removed from gym floors and the holes for them are covered by simple caps.

Such "strengthening" of the already existing objects in the area (creating a barrier field in width and depth) would cause a so-called tandem effect for VBIEDs. For example, the first row of barriers would slow the attacking vehicle while the other rows would lead to it being stopped or headed into safe spaces (including, for example, zones with walls to eliminate or reroute fragments after an explosion). 


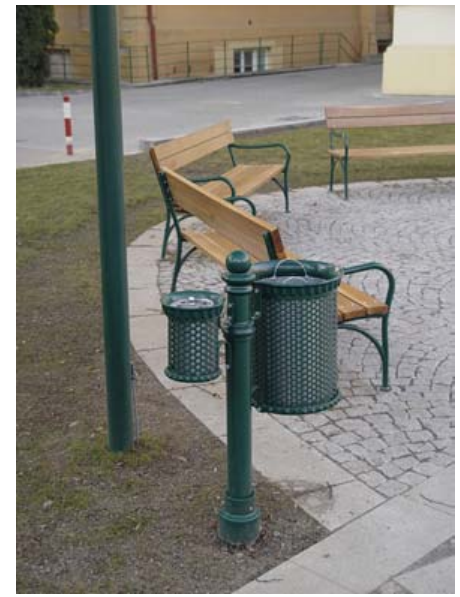

Figure 10 - Anchoring a wastebasket in a square - a discreet barrier Puc. 10 - Крепеж урны для мусора в сквере - неброское препятствие Слика 10 - Причвршћене корпе за отпатке на тргу - неупадљива препрека

\section{Conclusion}

VBIEDs are nowadays considered to be an effective weapon of asymmetric warfare. Preventing VBIED attacks is essential in order to diminish losses in human lives as well as material losses. The article shows some possibilities which could lead to this goal, especially the last mention barrier type called "weight down roadblock". This type of barriers is easy to move and it uses the weight of a VBIED itself to stop the vehicle.

\section{References}

ČTK. 2017. Nejtragičtější útok v historii Somálska. Exploze v Mogadišu zabila 276 osob. e15.cz. [Internet]. Available at: http://zpravy.e15.cz/zahranicni/udalosti/nejtragictejsi-utok-v-historii-somalskaexploze-v-mogadisu-zabila-276-osob-1338575. Accessed: 30.01 .2018 (in Czech).

-Headquarters, Department of the Army. 2013. Explosive ordnance disposal (EOD) operations. Washington DC: Headquarters, Department of the Army. Available http://armypubs.army.mil/epubs/DR_pubs/DR_a/pdf/web/atp4_32.pdf. at: Accessed: 30.01.2018. 
-ICRC. 1997. Convention on the Prohibition of the Use, Stockpiling, Production and Transfer of Anti-Personnel Mines and on their Destruction. Marshall Islands: ICRC. Available at: https://ihldatabases.icrc.org/ihl/INTRO/580. Accessed: 30.01.2018.

Zahraničí, Reuters \& Nárožná, V. 2017. Sebevražedná auta jako z Šíleného Maxe. To byly největší chlouby Islámského státu. Aktualne.cz. [Internet]. Available at: https://zpravy.aktualne.cz/zahranici/tank-v-nakladakusebevrazedna-auta-jako-z-sileneho-maxe-to-

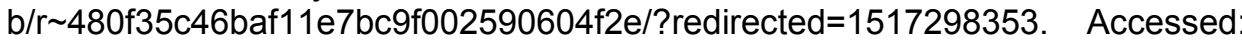
30.01.2018 (in Czech).

АСПЕКТЫ СНИЖЕНИЯ ПОСЛЕДСТВИЙ ПОДРЫВОВ

АВТОМОБИЛЕЙ, СОВЕРШЕННЫХ С ПОМОЩЬЮ САМОДЕЛЬНЫХ ВЗРЫВНЫХ УСТРОЙСТВ

Ян Дрозд, Зденек Фласар, Лудек Рак

Университет обороны в г. Брно, Факультет военного управления,

г. Брно, Республика Чехия

ОБЛАСТЬ: военные науки

ВИД СТАТЬИ: оригинальная научная статья

ЯЗЫК СТАТЬИ: английский

Резюме:

В данной статье представлены тактические и технические аспекты подрывов автомобилей, совершенных с помощью самодельных взрывных устройств. Характерной чертой подобных нападений является то, что они обычно применяются против „мягкой иели“, то есть людей, находящихся в зоне спланированного теракта в момент его осуществления. Цели нападения могут быть разными, но общим знаменателем является желание нанести как можно больший ущерб, особенно в виде большого количества жертв. В данной работе не затронуты вопросы искоренения терактов в целом, акцент делается на снижение негативных последствий после самого нападения. Исходя из предположения, что теракты подобного вида невозможно полностью извести, авторы данной статьи представляют решения по снижению негативных последствий для населения, посвящая особое внимание техническим параметрам различных стредств. Некоторые из предлагаемых мер отличаются простотой применения, в то время как более сложные из них требуют и значительных фринансовых вложений.

Ключевые слова: подрыв автомобиля самодельным взрывным устройством, барьер, террористы, оборона, взрыв. 
АСПЕКТИ УМАЊИВАЊА ЕФЕКАТА НАПАДА ИМПРОВИЗОВАНОМ ЕКСПЛОЗИВНОМ НАПРАВОМ У ВОЗИЛУ

Јан Дрозд, Зденек Фласар, Лудек Рак

Универзитет одбране у Брну, Факултет војног руковођења,

Брно, Чешка Република

ОБЛАСТ: војне науке

ВРСТА ЧЛАНКА: оригинални научни чланак

ЈЕЗИК ЧЛАНКА: енглески

Сажетак:

У раду су разматрани тактички и технички аспекти напада помоћу импровизоване експлозивне направе у возилу (vehicleborne improvised explosive device - VBIED). Овакви напади обично су усмерени против такозваних меких циљева, односно људи који се нађу у зони планираног терористичког акта у тренутку напада. Сврхе ових напада могу бити различите, а заједничко им је изазивање што већих последица, превасходно што већег броја људских жртава. Пошто се у раду полази од претпоставке да је немогуће у потпуности елиминисати нападе ове врсте, фрормулисана су могућа решења ради ублажавања њихових ефеката на људе, с посебним освртом на техничке параметре различитих средстава. Примена појединих мера и средстава је једноставнија, док нека сложенија средства захтевају знатније финансијске ресурсе.

Кључне речи: импровизована експлозивна направа у возилу, баријера, терористи, заштита, експлозија.

Paper received on / Дата получения работы / Датум пријема чланка: 30.01.2018. Manuscript corrections submitted on / Дата получения исправленной версии работы / Датум достављања исправки рукописа: 19.02.2018.

Paper accepted for publishing on / Дата окончательного согласования работы / Датум коначног прихватања чланка за објављивање: 21.02.2018.

(C) 2018 The Authors. Published by Vojnotehnički glasnik / Military Technical Courier (www.vtg.mod.gov.rs, втг.мо.упр.срб). This article is an open access article distributed under the terms and conditions of the Creative Commons Attribution license (http://creativecommons.org/licenses/by/3.0/rs/).

(c) 2018 Авторы. Опубликовано в «Военно-технический вестник / Vojnotehnički glasnik / Military Technical Courier» (www.vtg.mod.gov.rs, втг.мо.упр.срб). Данная статья в открытом доступе и распространяется в соответствии с лицензией «Creative Commons» (http://creativecommons.org/licenses/by/3.0/rs/).

() 2018 Аутори. Објавио Војнотехнички гласник / Vojnotehnički glasnik / Military Technical Courier (www.vtg.mod.gov.rs, втг.мо.упр.срб). Ово је чланак отвореног приступа и дистрибуира се у складу са Creative Commons licencom (http://creativecommons.org/licenses/by/3.0/rs/).

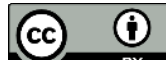

